THE GEOGRAPHIC IMAGINATION OF MODERNITY 



\section{The Geographic Imagination}

of Modernity

GEOGRAPHY, LITERATURE, AND PHILOSOPHY IN GERMAN ROMANTICISM

Chenxi Tang

STANFORD UNIVERSITY PRESS

STANFORD, CALIFORNIA 
Stanford University Press

Stanford, California

(C) 2008 by the Board of Trustees of the Leland Stanford Junior University. All rights reserved.

Publication assistance for this book was provided by the University of California at Berkeley.

No part of this book may be reproduced or transmitted in any form or by any means, electronic or mechanical, including photocopying and recording, or in any information storage or retrieval system without the prior written permission of Stanford University Press.

LIBRARY OF CONGRESS CATALOGING-IN-PUBLICATION DATA

Tang, Chenxi, I968-

The geographic imagination of modernity : geography, literature, and philosophy in German Romanticism / Chenxi Tang.

p. $\mathrm{cm}$.

Includes bibliographical references and index.

ISBN 978-0-8047-5839-0 (cloth : alk. paper)

I. Geography-Germany-History. 2. Geography-Philosophy-History. 3. Romanticism-Germany-History. 4. Germany-Intellectual life- 18 th century. 5. Germany-Intellectual life-I9th century. I. Title. G97.T36 2008

$910.01-\mathrm{dc2} 2$

2008004721

Typeset by Bruce Lundquist in Io/I2.5 Sabon 
For my mother 
